
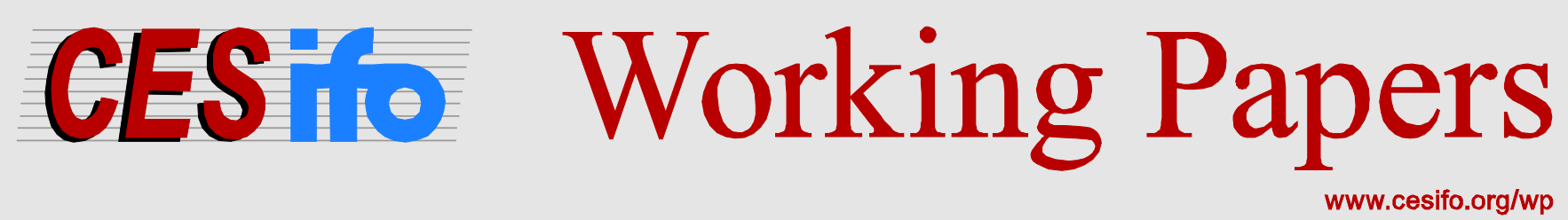

\title{
Is Capital Mobility Good for Public Good Provision?
}

\author{
Gregor Schwerhoff \\ Ottmar Edenhofer
}

CESIFO WORKING PAPER NO. 4420

CATEGORY 1: Public FinANCE

OCTOBER 2013
An electronic version of the paper may be downloaded
- from the SSRN website:
- from the RePEc website:
- from the CESifo website:
www.SSRN.com
www.RePEc.org
www.CESifo-group.org/wp

\section{CESifo}




\title{
Is Capital Mobility Good for Public Good Provision?
}

\begin{abstract}
We set up a general model on capital mobility which contains many of the models in the literature as special cases. The race to the bottom results not from a capital flight effect, but rather from a kind of Laffer curve effect in public good provision. Selectively introducing simplifying assumptions allows reproducing other models and understanding how they bias results in favor or against capital mobility. We then show how the net effect of capital mobility can be positive or negative within the same model depending on the relative capital endowment.
\end{abstract}

JEL-Code: D620, H210, H500, H730, H870.

Keywords: capital mobility, interjurisdictional competition, public good provision.

\author{
Gregor Schwerhoff \\ Potsdam Institute for Climate Impact \\ Research \\ PO Box 601203 \\ Germany-14412 Potsdam \\ schwerhoff@pik-potsdam.de
}

\author{
Ottmar Edenhofer \\ Potsdam Institute for Climate Impact \\ Research \\ PO Box 601203 \\ Germany - 14412 Potsdam \\ ottmar.edenhofer@pik-potsdam.de
}

October 2, 2013

Gregor Schwerhoff is grateful for financial support from the CLIPON project. Ottmar Edenhofer is grateful for financial support from the CREW and CLIPON project. 


\section{Introduction}

Based on models as in Zodrow and Mieszkowski (1986), the "race to the bottom" has taken a very prominent place in analyses of capital mobility and public good provision. It says that capital taxes drive capital out of the country when capital is mobile, thus providing an incentive to reduce public good provision. This however is far from a complete assessment of capital mobility. When countries are allowed to be non-identical, capital mobility introduces a range of effects. Using a general model we identify these effects and in which direction they affect utility and public good provision. Many models from the literature can be seen as focusing on specific effects by eliminating the others through their choice of assumptions.

This paper contributes to the literature in three ways. First, it explores the full range of effects which capital mobility has on public good provision in a general model with heterogenous countries. Next to the race to the bottom the most important one is the gains of trade effect which has been neglected due to the assumption of identical countries. Second, it points out in which way the urge to attain a tractable solution through simplifying assumptions biases results in favor or against capital mobility. Finally, it shows that within the general model, capital mobility can increase or decrease a country's utility and public good provision depending on its relative capital supply.

The full spectrum of effects reveals some aspects which have not been emphasized sufficiently in the literature. When the return to capital in a given country reduces due to an increase in taxes, less capital remains in the domestic economy. This "capital flight" is however offset through a reduction in capital payments the economy has to make when employing less capital. What is known as "race to the bottom" is actually a sort of Laffer curve effect for capital taxes since an increase in the tax rate reduces the tax base. Furthermore, any manipulation of the world interest rate through changes in taxes in a given country will be beneficial or detrimental to the manipulating country depending on whether or not it is a net borrower or lender of capital. In any case the downsides of capital mobility always have to be seen in relation to the upsides. Capital mobility increases the efficiency of the allocation of capital. This efficiency gain may outweigh the negative effects of the "race to the bottom".

This broad spectrum of effects has been manipulated in the literature in many ways. On the one extreme, there is the assumption of identical countries as in Bjorvatn and Schjelderup (2002). When countries are identical, then capital mobility must be harmful on the whole 
since the very reason why a country would want to introduce it is assumed away. On the other extreme, there is the assumption of a lump-sum tax in addition to the capital tax as in Ogawa and Wildasin (2009). With this assumption, the optimal capital tax is zero. This implies that the "race to the bottom" cannot occur and capital mobility must be beneficial.

Allowing countries to be non-identical shows how much the net effect of capital mobility depends on the exact setup. Countries which either import or export a lot of capital benefit strongly from the implied efficiency gain. Their level of utility and their public good provision is higher in this case since the efficiency gain outweighs the "race to the bottom". Countries which own about as much capital as they employ do not gain much from capital mobility. Nevertheless, they suffer from its negative effects. These countries may have lower utility and public good provision under capital mobility.

Wilson (1986) and Zodrow and Mieszkowski (1986) propose a small-country model of capital mobility and introduce many of the model features which became standard and also form the basis for the model in this paper. When countries are large enough to affect the international rate of return on capital, capital taxes and public good provision are obtained from a Nash equilibrium. This part of the theory was developed in Wildasin (1988), Wildasin (1989) and Hoyt (1991). In this case the race to the bottom occurs just as well, but it also becomes apparent that a tractable solution requires the assumption of identical countries. Even though a large variety of models has been developed, the features introduced in the early models did not lose their appeal. Bjorvatn and Schjelderup (2002) uses them and adds public goods with spillovers. Ogawa and Wildasin (2009) include environmental damage and lump-sum taxes. Eichner and Runkel (2012) further allows for intertemporal dynamics.

One of the few papers analyzing capital mobility in non-identical countries is Bucovetsky (1991). In this paper, two countries of different sizes are considered. The smaller country sets low capital taxes and thus attracts relatively large amounts of capital, effectively becoming a tax haven. In our model by contrast the decisive country heterogeneity is the relative capital endowment. The advantage of using cheap capital from abroad or of renting out abundant capital at attractive rates outweighs the distortion in choosing the tax rate.

Empirically, the effect of capital mobility on capital taxes seems valid. Bretschger and Hettich (2002) find that globalization has a negative effect on corporate taxes. Devereux et al. (2008) show that countries compete over forms of capital taxes and that strategic interaction in taxes is limited to open economies. This confirms that competition over tax rates does 
occur and that it is due to capital mobility (as opposed to yardstick competition).

It appears less straightforward to empirically establish the effect of capital mobility on public good provision. Many studies just investigate the relation between openness and government size. Liberati (2007) disentangles the effect of trade openness from that of capital mobility. The paper finds that capital mobility is negatively related to government expenditures, but also makes it clear that government expenditures are a problematic proxy for public goods. So while the race to the bottom is very prominent in the theoretical literature, the effect of capital mobility on welfare seems empirically elusive.

Wilson (1999) and Wilson and Wildasin (2004) provide reviews on tax competition, but do not attempt to assess the net effect of capital mobility. They compare different modeling approaches and departures from the standard assumptions from Zodrow and Mieszkowski (1986) like imperfectly competitive market structures, government commitment problems and political economy considerations. In contrast, this paper stays with the standard assumptions. The objective is to identify all relevant effects occurring with the standard assumptions and to understand how they work and how they depend on assumptions.

Section 2 describes the model and the socially optimal solution with and without mobile capital. Section 3 provides the Nash equilibrium with and without capital mobility and identifies the effects which make the difference. Section 4 shows which assumption eliminates which effect and how this biases the result. Section 5 discusses the relative strength of the effects depending on the capital endowment. Section 6 concludes.

\section{The Model}

There are $N$ countries. Each country has an endowment of assets $a_{i}$ and uses capital $k_{i}$. Total assets have to equal total capital:

$$
\sum_{i=1}^{N} a_{i}=\sum_{i=1}^{N} k_{i}
$$

Income is a function of capital,

$$
y_{i}=f_{i}\left(k_{i}\right)
$$

where $f_{i}$ fulfils the Inada conditions, $f_{i}(0)=0, f_{i}^{\prime}\left(k_{i}\right)>0, f_{i}^{\prime \prime}\left(k_{i}\right)<0, \lim _{k_{i} \rightarrow 0} f_{i}^{\prime}\left(k_{i}\right)=\infty$ and $\lim _{k_{i} \rightarrow \infty} f_{i}^{\prime}\left(k_{i}\right)=0$. In the general case, each country has an individual production function 
$f_{i}$. The return to capital received by asset owners equals the marginal productivity of capital less capital taxes

$$
f_{i}^{\prime}\left(k_{i}\right)-t_{i}=\rho
$$

This equation implicitly defines capital as a function of taxes and the interest rate, $k_{i}\left(t_{i}+\rho\right)$. The budget constraint for each country is

$$
y_{i}=x_{i}+g_{i}+\rho\left(k_{i}-a_{i}\right),
$$

where $x_{i}$ is consumption of the private good. $\rho a_{i}$ is the income of the country on the capital which it owns. $\rho k_{i}$ is the payment for the capital employed in production. $g_{i}$ is the amount of the public good provided by country $i$. It is financed by capital taxes,

$$
t_{i} k_{i}=g_{i}
$$

The amount of the public good enjoyed by country $i$ is given by the locally produced public good and possible spillovers from abroad of size $\beta \in[0,1]$,

$$
G_{i}=g_{i}+\beta \sum_{j \neq i} g_{j}
$$

For $\beta=0$, the public good is local, for $\beta=1$ it is global. Utility is derived from the private good and the level of the public good,

$$
U_{i}=U_{i}\left(x_{i}, G_{i}\right)
$$

We assume $U_{i}\left(0, G_{i}\right)=0$ and $U_{i x}>0 \forall x \geq 0$. We allow the utility function to be countryspecific.

\subsection{Efficient Resource Allocation without Capital Mobility}

When countries are not identical, the efficiency of the resource allocation depends on the options open to the social planner. Here, we assume that the social planner can only choose the optimal level of public good provision. In section 2.2 we consider the case where the social planner can also allocate capital optimally.

Since locally used capital must equal to assets we have $k_{i}=a_{i}$. Private good consumption 
and public good provision are thus given by $x_{i}=y_{i}-g_{i}-\rho\left(k_{i}-a_{i}\right)=f\left(a_{i}\right)-t_{i} a_{i}$ and $G_{i}=g_{i}+\beta \sum_{j \neq i} g_{j}=t_{i} a_{i}+\beta \sum_{j \neq i} g_{j}$. The social objective function is $\sum_{i=1}^{N} U_{i}$. Maximizing this with respect to $t_{i}$ yields as the efficiency condition for country $i$

$$
\frac{U_{i G}+\beta \sum_{j \neq i} U_{j G}}{U_{i x}}=1 \quad \forall i
$$

\subsection{Efficient Resource Allocation with Capital Mobility}

When the social planner is able to move capital between countries the optimization problem is $\max _{\left\{t_{i}, k_{i}\right\}} \sum_{i} U_{i}\left(f_{i}\left(k_{i}\right)-t_{i} k_{i}, t_{i} k_{i}+\beta \sum_{j \neq i} t_{j} k_{j}\right)$ subject to (1). The efficient allocation of capital and the public good (implicit in $t_{i}$ ) is given by (1) and the following system of $2 N-1$ equations

$$
\begin{aligned}
\frac{U_{i G}+\beta \sum_{j \neq i} U_{j G}}{U_{i x}} & =1 \quad \forall i \\
U_{i x}\left(f_{i}^{\prime}\left(k_{i}\right)-t_{i}\right)+(1-\beta) U_{i G} t_{i} & =U_{j x}\left(f_{j}^{\prime}\left(k_{j}\right)-t_{j}\right)+(1-\beta) U_{j G} t_{j}, \forall i, j .
\end{aligned}
$$

\section{Nash Equilibrium}

In order to isolate the effect of capital mobility on public good provision, we determine first the Nash equilibrium without capital mobility and then with capital mobility.

Countries make simultaneous decisions on the tax rate $t_{i}{ }^{1}$, which is the strategic variable, and take the other countries' tax rate as given. The first order condition from maximizing the utility function is

$$
M R S_{i}=\frac{U_{i G}}{U_{i x}}=-\frac{\frac{d x_{i}}{d t_{i}}}{\frac{d G_{i}}{d t_{i}}} \quad \forall i
$$

The reaction of private and public good consumption to the tax rate, $\frac{d x_{i}}{d t_{i}}$ and $\frac{d G_{i}}{d t_{i}}$, will depend on whether or not there is capital mobility.

\footnotetext{
${ }^{1}$ This is the standard assumption. Making $g_{i}$ the strategic variable is equally plausible, but gives different results. See Wildasin (1988).
} 


\subsection{Nash Equilibrium without Capital Mobility}

As in section 2.1, utility of an individual country is given by $U_{i}\left(f\left(a_{i}\right)-t_{i} a_{i}, t_{i} a_{i}+\beta \sum_{j \neq i} g_{j}\right)$. The first order condition of maximizing this is

$$
M R S_{i}=-\frac{-k_{i}}{k_{i}}=1 \quad \forall i
$$

The Nash equilibrium is thus implicitly defined by this equation system of $N$ equations.

\subsection{Nash Equilibrium with Capital Mobility}

When capital is mobile, asset holdings can differ from capital input. Income is thus in its general form from equation (4), $x_{i}=f\left(k_{i}\right)-t_{i} k_{i}-\rho\left(k_{i}-a_{i}\right)$. Since capital now depends on taxes, we have

$$
\begin{aligned}
\frac{d x_{i}}{d t_{i}} & =f_{i}^{\prime}\left(k_{i}\right) \frac{d k_{i}}{d t_{i}}-k_{i}-t_{i} \frac{d k_{i}}{d t_{i}}-\frac{d \rho}{d t_{i}}\left(k_{i}-a_{i}\right)-\rho \frac{d k_{i}}{d t_{i}} \\
\frac{d G_{i}}{d t_{i}} & =k_{i}+t_{i} \frac{d k_{i}}{d t_{i}}+\beta \sum_{j \neq i} t_{j} \frac{d k_{j}}{d t_{i}} .
\end{aligned}
$$

The first, third and fifth term of equation (13) cancel out, due to the interest rate equation (3). The first order condition thus is

$$
M R S_{i}=-\frac{-k_{i}-\frac{d \rho}{d t_{i}}\left(k_{i}-a_{i}\right)}{k_{i}+t_{i} \frac{d k_{i}}{d t_{i}}+\beta \sum_{j \neq i} t_{j} \frac{d k_{j}}{d t_{i}}} \quad \forall i
$$

where

$$
\begin{aligned}
k_{i}^{\prime} & =\frac{1}{f_{i}^{\prime \prime}\left(k_{i}\right)}<0, \\
\frac{d k_{i}}{d t_{i}} & =k_{i}^{\prime} \frac{\sum_{j \neq i} k_{j}^{\prime}}{\sum_{j} k_{j}^{\prime}}=\frac{\varepsilon_{i} k_{i}}{\rho+t_{i}} \frac{\sum_{j \neq i} \frac{\varepsilon_{j} k_{j}}{\rho+t_{j}}}{\sum_{j} \frac{\varepsilon_{j} k_{j}}{\rho+t_{j}}}<0, \\
\frac{d k_{j}}{d t_{i}} & =-k_{i}^{\prime} \frac{k_{j}^{\prime}}{\sum_{j} k_{j}^{\prime}}=-\frac{\varepsilon_{i} k_{i}}{\rho+t_{i}} \frac{\frac{\varepsilon_{j} k_{j}}{\rho+t_{j}}}{\sum_{j} \frac{\varepsilon_{j} k_{j}}{\rho+t_{j}}}>0, \\
\frac{d \rho}{d t_{i}} & =-\frac{k_{i}^{\prime}}{\sum_{j} k_{j}^{\prime}}<0 .
\end{aligned}
$$


$\varepsilon_{i}=\left[f_{i}^{\prime \prime}\left(k_{i}\right) \frac{k_{i}}{f_{i}^{\prime}\left(k_{i}\right)}\right]^{-1}<0$ is the inverse of the elasticity of the derivative of the production function with respect to capital. The derivations for (17) to (19) can be found in Wildasin (1989).

In order to determine the net effect of capital mobility on public good provision, we will go through the difference between the Nash equilibrium with capital mobility, equation (12), and without capital mobility, equation (15).

\section{The Free Rider Effect}

Comparing the Nash equilibrium with capital mobility to the efficient allocation characterized in equation (8) shows that the term $\beta \sum_{j \neq i} \frac{\partial U_{j}}{\partial G_{j}}$ does not appear in the Nash solution. The reason is that countries do not internalize the effect of their public good provision on other countries. This, however, is not due to capital mobility. It occurs when countries choose their public good level even without capital mobility, see equation (12).

\section{The Capital Flight Effect}

When the government of country $i$ increases taxes, the amount of capital used locally, $k_{i}$, reduces. With less taxes available the local industry can produce less. The reason is that the tax reduces the return to capital, so that the capital moves abroad until the return to capital is again the same everywhere. This is the capital flight effect often encountered in the public discourse on the provision of public goods. It can be found in the expression $f_{i}^{\prime}\left(k_{i}\right) \frac{d k_{i}}{d t_{i}}$ in equation (13). An increase in taxes in country $i$ thus has a negative effect on country $i$, since less capital is available for production.

On the other hand, when less capital is used, the economy has to pay less. This is reflected in the third and fifth term in equation (13). An increase in taxes in country $i$ thus also has a positive effect on country $i$, since it reduces expenditure for capital.

In equilibrium the marginal productivity of capital is equal to the rental price of capital. As a consequence, the positive and the negative effects mentioned above cancel out exactly. This is what allows the simplification of equation (13) to the expression in the numerator of equation (15).

\section{World Interest Rate Effect}

The term $\frac{d \rho}{d t_{i}}\left(k_{i}-a_{i}\right)$ represents the effect of a change in taxes $t_{i}$ on the world interest rate. It is important to country $i$ since the world interest rate affects the payments on net capital holdings $k_{i}-a_{i}$. 
Equation (19) reveals that an increase in taxes $t_{i}$ lowers the world interest rate. Whether a lower world interest rate would harm or benefit country $i$ depends on whether country $i$ is a net capital importer $\left(k_{i}-a_{i}>0\right)$ or exporter $\left(k_{i}-a_{i}<0\right)$. For a capital importer, the world interest rate effect provides an incentive to provide more of the public good. For the exporter it provides an incentive to provide less of the public good. Public good provision thus provides a possibility to manipulate the terms of trade.

\section{Laffer Curve Effect}

The relation between capital taxes and public good provision under capital mobility could be described as a "Laffer curve". Without capital mobility, $k_{i}$ is independent of $t_{i}$ so that $\frac{d g_{i}}{d t_{i}}=k_{i}>0$ and $\frac{d^{2} g_{i}}{d^{2} t_{i}}=0$. With capital mobility, $k_{i}$ does depend on $t_{i}$, so that $\frac{d g_{i}}{d t_{i}}=k_{i}+t_{i} \frac{d k_{i}}{d t_{i}}$ and $\frac{d^{2} g_{i}}{d^{2} t_{i}}=2 \frac{d k_{i}}{d t_{i}}+\frac{d^{2} k_{i}}{d^{2} t_{i}}<0$.

Without capital mobility the marginal return in terms of the public good to an increase in taxes is positive and constant. With capital mobility the marginal return is diminishing. It is positive for low values of $t_{i}$ and negative for high values. These diminishing returns to taxation makes it less attractive to supply the public good. This is the effect which causes the "race to the bottom" identified in Zodrow and Mieszkowski (1986) and throughout the literature.

\section{The Spill Back Effect}

The Laffer curve effect is partly offset by the "spill back" effect $\beta \sum_{j \neq i} t_{j} \frac{d k_{j}}{d t_{i}}>0$. An increase in taxes in country $i$ increases capital available in the other countries, $\frac{d k_{j}}{d t_{i}}>0$ and therefore also their local public good provision, $\frac{d g_{j}}{d t_{i}}>0$. Therefore, an increase in taxes $t_{i}$ triggers a "spill out" of capital which then partly "spills back" as additional public good provided abroad.

When spillovers are perfect $(\beta=1)$ and countries are identical the Laffer curve and the spill back effect offset each other, so that capital mobility makes no difference at all. This has been shown in Bjorvatn and Schjelderup (2002), Proposition 1. When $\beta<1$, the Laffer curve effect dominates. In this case, the Nash equilibrium will be less efficient than the social optimum from section 2.2.

\section{Gains of Trade Effect}

When we compare the Nash equilibrium with capital mobility to the Nash equilibrium without capital mobility, we have to recall the motivation for introducing capital mobility. 
When countries are not identical, they gain from capital mobility just as they gain from trade in models of more than one good. Capital mobility can be seen as trade of capital against the final good. Countries with low productivity can lend capital and receive the final good in return. Countries with a high productivity do the reverse.

The gains from trade have a positive effect on welfare. Income increases and with it public good provision. When capital mobility is introduced, capital is re-allocated. Since taxes are levied not on private good consumption, but on capital employed locally, tax rates will change. Capital exporters employ less capital at home, but will have a higher demand for the public good due to the increase in income. They therefore have to take a higher tax rate on the capital they have at home. The reverse holds for capital importers.

The capital exporters who have to increase their tax rate will be most affected by the Laffer curve effect, so that the gains of trade and the Laffer curve effect interact. The details of this will be discussed in Section 4.3.

\section{Summary}

What can we say at this point about the effect of capital mobility on public good provision? There is no clear-cut net effect, the net result will depend on the implicit assumptions on relative strengths of the effects. But we can summarize which effects play a role and in which direction.

The free rider effect is due to the spillovers in the public good and does not arise from capital mobility. The capital flight effect is offset entirely by the reduced expenses for capital. These two effects thus play no role in an assessment of capital mobility. The direction of the world interest rate effect depends on the status of the country as a capital importer or exporter. For a small country the effect will be minor, since it cannot change the world interest rate significantly. The Laffer curve effect clearly has a negative effect on public good provision, while the spill back and the gains of trade effects have a positive effect.

Since the assumptions play a vital role, we will next go through the most important assumptions made in the literature and see how they determine the result.

\section{Simplifying Assumptions}

In the literature, clear answers on the effect of capital mobility on utility and public good provision have been obtained through the introduction of simplifying assumptions. Here we 
will take a systematic look at which assumption eliminates which effects and reaches what kind of solution.

\subsection{Assumption: Identical Countries}

The only simplifying assumption made by Bjorvatn and Schjelderup (2002) is that of identical countries. Assuming identical countries implies setting $k_{i}=a_{i}$ in equation (15). We thus have

$$
M R S_{i}=-\frac{-k_{i}}{k_{i}+t_{i} \frac{d k_{i}}{d t_{i}}+\beta \sum_{j \neq i} t_{j} \frac{d k_{j}}{d t_{i}}} .
$$

For identical countries, Bjorvatn and Schjelderup (2002) show that $\frac{d k_{i}}{d t_{i}}=\frac{1}{f^{\prime \prime}(k)} \frac{N-1}{N}$ and $\frac{d k_{j}}{d t_{i}}=\frac{1}{f^{\prime \prime}(k)} \frac{1}{N}$, so that

$$
M R S=\frac{k}{k+(1-\beta) t \frac{1}{f^{\prime \prime}(k)} \frac{N-1}{N}} .
$$

Except for a minor algebraic error (see Appendix A) this is exactly what Bjorvatn and Schjelderup (2002) find. The equilibrium is now in a very handy format since the equilibrium tax rate is implicitly defined by this one equation, whereas in the general solution it required solving a system of $N$ equations. This makes comparison easier.

The assumption of identical countries has eliminated the gains of trade effect since identical countries do not benefit from trade, including capital trade, in this kind of model. Absent the reason for the introduction of capital mobility, its introduction can at best make no difference on welfare. The world interest rate effect is eliminated since all countries use exactly as much capital as they hold. The total effect of capital mobility is now the sum of the Laffer curve and the spill back effect.

\subsection{Assumption: Small Countries}

A very common assumption is that of a "small country" which cannot influence the interest rate significantly. This assumption can be written as $\frac{d \rho}{d t_{i}}=0$. The first order condition becomes

$$
M R S_{i}=-\frac{-k_{i}}{k_{i}+t_{i} \frac{d k_{i}}{d t_{i}}+\beta \sum_{j \neq i} t_{j} \frac{d k_{j}}{d t_{i}}} .
$$

The assumption eliminates the world interest rate effect. Making only this assumption does not allow calculating the tax rate from a single equation as it was possible under the assumption of identical countries. For this reason, many papers add further assumptions. Zodrow 
and Mieszkowski (1986) and Keen and Marchand (1997) for example add identical countries and local pollution.

If this assumption is not made, the equilibrium is a Nash equilibrium. Among the few papers not making it are Wildasin (1988), Hoyt (1991), Bucovetsky (1991), Bjorvatn and Schjelderup (2002) and Ogawa and Wildasin (2009).

\subsection{Assumption: Local Public Good}

Another very frequent assumption is that the public good is local and does not spill over to other countries, $\beta=0$. The first order condition becomes

$$
M R S_{i}=-\frac{-k_{i}-\frac{d \rho}{d t_{i}}\left(k_{i}-a_{i}\right)}{k_{i}+t_{i} \frac{d k_{i}}{d t_{i}}} .
$$

The assumption eliminates the spill back effect. Since the spill back effect counteracts the Laffer curve effect, making this assumption increases the inefficiency of the introduction of capital mobility.

Wildasin (1988) and Wildasin (1989) work with this case and derive equations (16) to (19) in this context. With these equations the sign of the individual effects can be determined as shown in Section 3.2. But still the full equilibrium of $N$ equations must be solved to determine the equilibrium value for capital taxes of an individual country.

Bucovetsky (1991) builds on Wildasin (1988) and explores the properties of competition between non-identical countries. He does not provide an evaluation of capital mobility, however. He compares asymmetric competition to full merger of the two regions. An evaluation of capital mobility instead requires a comparison with the situation of the two countries without capital mobility.

\subsection{Assumption: Lump-Sum Taxes}

Ogawa and Wildasin (2009) provides a model with the setup of Section 2 with one additional feature: There is environmental pollution proportional to capital use: $e_{i}=a k_{i}+a \beta\left(a_{i}-k_{i}\right)$. Setting $a=0$ the model fits exactly into the framework used here. In order to solve the model they introduce the simplifying assumption of lump-sum taxes. The budget constraint is thus given as $y_{i}=x_{i}+g_{i}+\rho\left(k_{i}-a_{i}\right)-T_{i}$ and public good provision is $g_{i}=T_{i}+t_{i} k_{i}$.

When lump sum taxes are available, the optimal amount of capital taxes is zero. This 
is what Ogawa and Wildasin (2009) find for $a=0$. With respect to the effects of capital mobility, however, it is a rather crude tool. The world interest rate effect, the Laffer curve effect and the spill back effect are all eliminated since the capital allocation is not distorted. The gains of trade effect is not eliminated and indeed this effect occurs in Ogawa and Wildasin (2009) since they allow countries to be non-identical.

Lump-sum taxes are usually not available in practice, which is why capital taxes are so widely treated in the literature on public good provision and capital mobility. Compared to the general model presented above, lump-sum taxes introduce a bias in favor of capital mobility since they eliminate all the negative effects of capital mobility and preserve a positive effect.

Eichner and Runkel (2012) use a similar framework to Ogawa and Wildasin (2009), but extend it by introducing intertemporal considerations. The time dimension makes the total amount of capital endogenous, which is a new feature in this strand of literature. Concerning the effects discussed here, however, the same applies as for Ogawa and Wildasin (2009).

\subsection{Summary}

Having gone through the assumptions made in the literature and the corresponding simplifications, we can summarize them in this way:

\begin{tabular}{l|l} 
Assumption & Effects Eliminated \\
\hline Identical Countries & World Interest Rate Effect, Gains of Trade Effect \\
Small Countries & World Interest Rate Effect \\
Local Public Good & Spill Back Effect \\
Lump-Sum Taxes & World Interest Rate Effect, Laffer Curve Effect, Spill Back Effect
\end{tabular}

Table 1: Overview of assumptions and the effects eliminated with it

Of the four simplifying assumptions in the table only identical countries and, trivially, lump-sum taxes permit expressing the equilibrium value for capital taxes in a single equation. Both these assumptions are strongly biased. In the case of identical countries the positive effect of capital mobility, gains from trade, is ruled out. In the case of lump-sum taxes all the negative effects of capital mobility are ruled out.

This explains the predominance of the race to the bottom: It is the main effect when countries are assumed to be identical and the assumption of identical countries is the unique assumption which allows for a non-trivial and tractable solution. 


\section{Cost Benefit Analysis}

Up to this point we have seen which effects occur under capital mobility, in which direction they affect utility or public good provision and how they are affected by simplifying assumptions. In this section we will take a closer look at their relative strengths. For a given level of capital endowment $a_{i}$ we compare the situation with and without capital mobility. Depending on $a_{i}$ the gains of trade will vary dramatically in relative importance. The net impact of capital mobility will thus be positive or negative at different levels of $a_{i}$.

In the setup of the model we allowed countries to differ in their production function $f_{i}$, their utility function $U_{i}$ and capital endowment $a_{i}$. The amount of capital employed by the economy $k_{i}$ is endogenously determined by the production and utility function. The net capital endowment $k_{i}-a_{i}$ is thus a good measure for the country's characteristics. We thus establish whether capital mobility is profitable or not for a given country depending on the capital endowment. We assume that there is at least one other country with positive assets $a_{j}>0$ and compare countries with different capital endowments $a_{i}$ leaving all else equal.

A country which imports or exports large amounts of capital benefits from capital mobility since it strongly improves its capital allocation. A country where the endowment is close to the capital employed in equilibrium cannot improve its utility level very much.

In the following subsections we show the net of all the effects listed in Section 3.2 for countries with certain capital endowment levels. Since not much can be said in the general case we subsequently introduce assumptions which allow us to make additional statements.

\subsection{The General Case}

We start with a country with a zero capital endowment, $a_{i}=0$. In autarky, income will be given by $x_{i}=f\left(a_{i}\right)=0$. Utility therefore is zero as well. With capital mobility, however, the country can borrow capital and produce. Since we assumed that the marginal productivity near zero is very high, there is an amount of capital where the value of produced goods is higher than factor payments for capital. The country would thus retain a positive amount of production which it can allocate optimally to private consumption and public good provision. Even though the race to the bottom is effective, such a country would be better off with capital mobility.

Proposition 1 At capital endowment levels at and near zero, a country has higher utility 
and provides more of the public good under capital mobility than in autarky.

This proposition says that there are cases where the capital gains effect is stronger than the net of all other effects, including the Laffer curve effect, which is commonly known as the race to the bottom.

The statement is rather weak, which is owed to the generality of the model. In the most general model it is not even clear that there must be a a capital endowment level where the country has lower utility under capital mobility than under autarky. A candidate for a country suffering losses from capital mobility is one which uses as much capital as it owns in equilibrium $\left(a_{i}=k_{i}\right)$. In this case the gains from trade are zero and the world interest rate effect as well. However the spill back effect may be stronger than the Laffer curve effect. The loss of capital abroad may thus actually be a benefit since the reduction in public good provision $g_{i}$ may be less than the increase of the public good abroad, $\beta \sum_{j \neq i} g_{j}$.

\subsection{Local Public Goods}

When the public good is local and therefore does not spill over to other countries, $\beta=0$, the spill back effect is zero. In this case, a country which has zero net capital imports, $a_{i}=k_{i}$, in equilibrium has no benefits from capital mobility, but does suffer from the Laffer curve effect. Using high indices to label the Nash equilibrium under autarky and capital mobility we have

$$
M R S_{i}^{M o b}=-\frac{-k_{i}}{k_{i}+t_{i} \frac{d k_{i}}{d t_{i}}}>1=M R S_{i}^{A u t}
$$

The country would have the same amount of capital available under autarky as under capital mobility. But due to the Laffer curve effect (or race to the bottom), the allocation of capital between private consumption and public good provision would be less efficient under capital mobility. Such a country, therefore has lower utility and lower public good provision under capital mobility than in autarky.

Proposition 2 Let the public good be local. Then a country with a capital endowment at and near zero has higher utility and provides more of the public good under capital mobility than in autarky. A country which uses as much capital it owns in equilibrium has lower utility and provides less of the public good under capital mobility than in autarky.

A country with a very low capital endowment benefits more from capital mobility than it suffers from the race to the bottom. Analogously, we can conjecture that a country with a 
very high capital endowment benefits from capital mobility as well since it earns more from renting out its capital than from employing it at low marginal utility itself. In the general model however it is not clear how the gains from trade can be compared with the loss from the race to the bottom when capital $k_{i}$ results from general equilibrium. We thus introduce more simplifying assumption.

\subsection{A Small Country and Local Public Goods}

We assume that (i) the public good is local, $G_{i}=g_{i}$, (ii) country $i$ is so small that it cannot influence the world interest rate and (iii) utility is quasilinear, $U_{i}\left(x_{i}, G_{i}\right)=x_{i}+b \ln \left(G_{i}\right)$.

In autarky, country $i$ has a private good consumption of $x_{i}=f\left(a_{i}\right)-t_{i} a_{i}$ and public good consumption of $G_{i}=g_{i}=t_{i} a_{i}$. The first order condition for country $i$ is $\frac{b}{t_{i} a_{i}}=1$, so that $t_{i}=\frac{b}{a_{i}}$. Utility in autarky is thus $U_{i}^{A u t}=f\left(a_{i}\right)-b+b \ln (b)$.

In capital mobility, country $i$ has a private good consumption of $x_{i}=f\left(k_{i}\right)-t_{i} k_{i}-\rho\left(k_{i}-a_{i}\right)$ and public good consumption of $G_{i}=g_{i}=t_{i} k_{i}$. Capital employed by country $i$ and the tax rate are determined from the first order condition $\frac{b}{t_{i} k_{i}}=-\frac{-k_{i}}{k_{i}+t_{i} \frac{d k_{i}}{d t_{i}}}$ and the interest rate condition $f_{i}^{\prime}\left(k_{i}\right)-t_{i}=\rho$. We can express the utility under capital mobility as $U_{i}^{A u t}=$ $f\left(k_{i}\right)-t_{i} k_{i}-\rho\left(k_{i}-a_{i}\right)+b \ln \left(t_{i} k_{i}\right)$.

Utility in autarky is thus a concave function in $a_{i}$. With capital mobility the variables $k_{i}$ and $t_{i}$ are independent of the capital endowment $a_{i}$. Utility in capital mobility is thus a linear function in $a_{i}$. This is quite intuitive. An autarkic country has to use its own production possibilities and these feature diminishing marginal productivity. In capital mobility, capital can be rented out and always fetches the international interest rate. For high levels therefore, utility must be higher in capital mobility. In addition to Propositions 1 and 2, we thus have the following.

Proposition 3 Let the public good be local, utility be quasilinear and consider a small country. Then a country with a very high capital endowment has higher utility under capital mobility than in autarky.

The situation described in Proposition 3 is represented in the left panel of figure 1. For very low and very high capital endowments, utility under capital mobility is higher. But somewhere in between the country is better off in autarky. The situation in the center panel cannot be excluded under the assumptions in Proposition 2. At very low levels capital 
mobility is better and at some point autarky must be better. But potentially autarky is better even for very large capital endowments. Finally, under the assumptions in Proposition 1 we cannot even rule out the situation on the right panel. We know that for low capital endowments, capital mobility has to be better. The spill back effect, however, may be so strong that capital mobility is better at all levels of capital endowment.

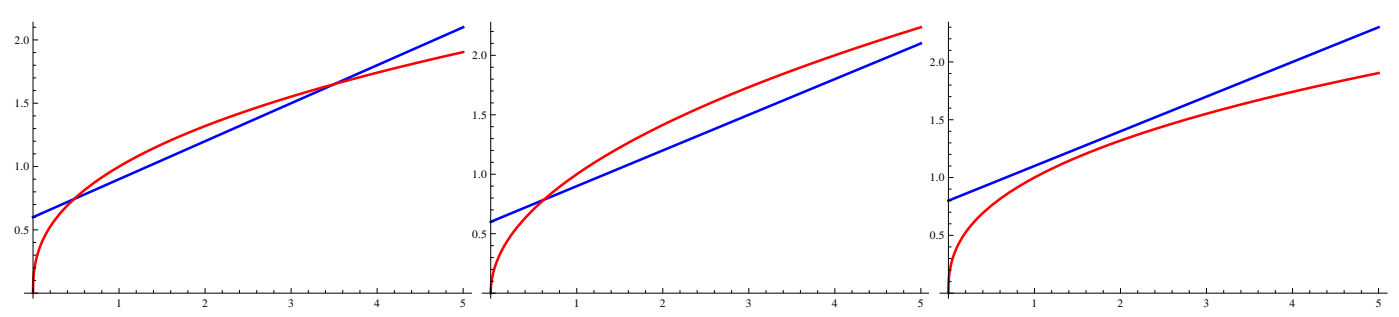

Figure 1: Relative position of utility in capital mobility (blue) and autarky (red). See text for details.

The relation described in Proposition 3 and in the left panel of Figure 1 is quite intuitive. For countries which benefit strongly from capital mobility, this benefit outweighs the disadvantages of the race to the bottom. For countries which are so unfortunate that they do not benefit from capital mobility at all, the race to the bottom makes them lose from capital mobility. The assumption of identical countries thus forces the view exclusively on this case.

\section{Conclusion}

It is in the nature of models that any change in assumptions changes the result. In the case of capital mobility, however, it seems particularly pervasive that assumptions made for the benefit of simplicity entirely eliminate either the benefits or the downsides of capital mobility. This paper points out which assumptions neglect which aspect and provides some insights on the general case.

The paper also points out the importance of the right frame of reference. Since so many papers work with identical countries, a merger of the regions concerned seems an efficiencyenhancing alternative. When non-identical regions are merged, however, having a unique level of taxation brings its own inefficiency. Likewise, abolishing capital mobility would eliminate the gains of trade and thus introduce another inefficiency. Simply observing that there is a race to the bottom is thus of no great value. Instead, a comparison between inefficiencies of 
different possible solutions is needed.

The standard model investigated here is used intensively in the literature with some variations. However, since the capital flight effect is entirely offset by lower capital expenses the model is an insufficient explanation for the concern on capital taxation and environmental regulation in the public discourse. For an understanding of these concerns dynamic effects or the effects of capital flight on other production factors such as labor will need to be considered. 


\section{References}

Bjorvatn, K. and Schjelderup, G. (2002). Tax competition and international public goods. International Tax and Public Finance, 9:111-120.

Bretschger, L. and Hettich, F. (2002). Globalisation, capital mobility and tax competition: theory and evidence for oecd countries. European journal of political economy, 18(4):695716.

Bucovetsky, S. (1991). Asymmetric tax competition. Journal of Urban Economics, 30(2):167181.

Devereux, M. P., Lockwood, B., and Redoano, M. (2008). Do countries compete over corporate tax rates? Journal of Public Economics, 92(5):1210-1235.

Eichner, T. and Runkel, M. (2012). Interjurisdictional spillovers, decentralized policymaking, and the elasticity of capital supply. The American Economic Review, 102(5):2349-2357.

Hoyt, W. (1991). Property taxation, nash equilibrium, and market power. Journal of Urban Economics, 30(1):123-131.

Keen, M. and Marchand, M. (1997). Fiscal competition and the pattern of public spending. Journal of Public Economics, 66(1):33 - 53.

Liberati, P. (2007). Trade openness, capital openness and government size. Journal of Public Policy, 27(02):215-247.

Ogawa, H. and Wildasin, D. (2009). Think locally, act locally: Spillovers, spillbacks, and efficient decentralized policymaking. The American Economic Review, 99(4):1206-1217.

Wildasin, D. (1988). Nash equilibria in models of fiscal competition. Journal of Public Economics, 35(2):229-240.

Wildasin, D. (1989). Interjurisdictional capital mobility: Fiscal externality and a corrective subsidy. Journal of Urban Economics, 25(2):193-212.

Wilson, J. (1986). A theory of interregional tax competition. Journal of Urban Economics, 19(3):296-315. 
Wilson, J. and Wildasin, D. (2004). Capital tax competition: bane or boon. Journal of Public Economics, 88(6):1065-1091.

Wilson, J. D. (1999). Theories of tax competition. National tax journal, 52:269-304.

Zodrow, G. and Mieszkowski, P. (1986). Pigou, tiebout, property taxation, and the underprovision of local public goods. Journal of Urban Economics, 19(3):356-370. 


\section{A Error in Bjorvatn and Schjelderup (2002)}

Equation (19) in Bjorvatn and Schjelderup (2002) contains a minor error which explains the apparent different between their result and our equation (21). Equation (15) in Bjorvatn and Schjelderup (2002) can be written as

$$
M R S_{i}=-\frac{\frac{\partial x_{i}}{\partial t_{i}}}{\frac{\partial G_{i}}{\partial t_{i}}} .
$$

For the numerator we have $\frac{\partial x_{i}}{\partial t_{i}}=-k$ when countries are symmetric. For the denominator we use that under symmetry $\xi_{i, j}=\frac{\partial k_{j}}{\partial t_{i}} \frac{t_{i}}{k_{j}}=-\frac{1}{N-1} \frac{\partial k_{i}}{\partial t_{i}} \frac{t_{i}}{k_{j}}=-\frac{1}{N-1} \xi_{i}$. Using this we can write

$$
\begin{aligned}
\frac{\partial G_{i}}{\partial t_{i}} & =k_{i}\left(1+\xi_{i}\right)+\beta \sum_{j \neq i} k_{j} \xi_{i, j} \\
& =\left[k_{i}(1+\xi)+\beta \sum_{j \neq i} k_{j}\left(-\frac{1}{N-1} \xi_{i}\right)\right] \\
& =k\left[1+\xi-\beta(N-1) \frac{1}{N-1} \xi\right] \\
& =k[1+\xi(1-\beta)] .
\end{aligned}
$$

This implies

$$
M R S=\frac{1}{1+\xi(1-\beta)}
$$

instead of equation (19) in Bjorvatn and Schjelderup (2002). 